\title{
Geochemical mobility of arsenic in the surficial waters from Argentina
}

\author{
Alicia Daniela Robles ${ }^{1,2}$ - Paula Polizzi ${ }^{1,2} \cdot$ María Belén Romeroo $^{1,2}$. \\ Leila Natalia Chiodi Boudet ${ }^{1,2} \cdot{\text { Sandra } \text { Medici }^{3} \text { - Agustín Costas }}^{3}$. \\ Marcela Gerpe ${ }^{1,2}$
}

Received: 4 June 2015/ Accepted: 15 November 2016

(C) Springer-Verlag Berlin Heidelberg 2016

\begin{abstract}
The presence of arsenic (As) in surface water constitutes an important environmental risk, where mobility and adsorption processes are responsible for its behavior in the sediment-water interface. Therefore, the assessment of adsorption, mobility and water availability of arsenic in freshwater sediments, with agricultural, livestock and urban soil uses was performed. Arsenic concentrations in sediments ranged from 5.4 to $15.9 \mathrm{mg} \mathrm{kg}^{-1}$ (total) and 2.8 to $6.5 \mathrm{mg} \mathrm{kg}^{-1}$ (labile), and those of iron and manganese were $11,563-23,500$ and $140.6-662.1 \mathrm{mg} \mathrm{kg}^{-1}$, respectively. The As levels in water were significantly lower than those of sediments. Results would suggest that As co-precipitation and adsorption on $\mathrm{Fe}$ oxides are probably the major route of immobilization, determining its low lability. Manganese did not present an outstanding contribution to the retention, and cation-exchange capacity, $\mathrm{pH}$ and organic matter of sediments did not show an influence on the mobility of As.
\end{abstract}

Keywords Arsenic Surface sediment - Adsorption · Mobility

This article is part of a Topical Collection in Environmental Earth Sciences on "3RAGSU", guest edited by Daniel Emilio Martinez.

Alicia Daniela Robles

aliciadrobles@mdp.edu.ar

1 Toxicología Ambiental, Departamento de Ciencias Marinas, Instituto de Investigaciones Marinas y Costeras, Facultad de Ciencias Exactas y Naturales, Universidad Nacional de Mar del Plata, Funes 3350, 7600 Mar del Plata, Argentina

2 Consejo Nacional de Investigaciones Científicas y Técnicas (CONICET), Buenos Aires, Argentina

3 Laboratorio de Análisis Fares Taie, Magallanes 3019, $1^{\circ}$ piso, 7600 Mar del Plata, Argentina

\section{Introduction}

The presence of As in surface and groundwater is a global problem, which is associated with the diseases Chronic Endemic Regional Hydroarsenicism (HACRE in Spanish) and also with cancer in different organs (skin, lung, liver), affecting the population exposed to this metalloid through drinking water (Heck et al. 2009; Mandal and Suzuki 2002). In Argentina, the maximum limit of As in water is $10 \mu \mathrm{g} \mathrm{L}^{-1}$ (CAA 2007; WHO 2006), and in some locations it is known that levels of arsenic in groundwater and surface water exceed this limit. The mobility of arsenic (As) in the freshwater-sediment interface is relevant to assess the impact on the water column, mainly in water bodies with probable use as drinking water, livestock water and/or crop irrigation (Pérez Carrera and Fernández Cirelli 2005; Puntoriero et al. 2015; Rosso et al. 2011). Mobility from soils and sediments is the combined result of biogeochemical processes linked to hydrological factors (Fendorf et al. 2008), having influence on their geochemistry. In this way, changes in water chemistry $(\mathrm{pH}$, redox potential, conductivity and temperature) and certain parameters of sediments (organic matter-OM, cation-exchange capacity-CEC, grain size, $\mathrm{pH}$ ) result in the release of As from solid phases by several desorption pathways. Arsenic mobility in freshwater environments is influenced mainly by adsorption on iron oxides and hydroxides, and probably those with aluminum and manganese oxides (De Mello et al. 2006; Root et al. 2007; Ma et al. 2015). Iron oxides have been mainly recognized as effective As scavengers; in fact, the co-precipitation of arsenic with these ligands is used as an effective treatment technology of remediation, due to the remotion of As (Smedley et al. 2005; Mohan and Pittman 2007). Besides, the arsenic mobility is closely related to the labile fraction, the unstable fraction, in soils 
and sediments, being important in terms of environmental contamination, since it may easily be available for organisms.

In Chaco-Pampean plain, the source of As in groundwater has been attributed to the presence of volcanic ash and glass associated with loessic sediments of the region (Smedley et al. 2005; Nicolli et al. 2012; Puntoriero et al. 2014). The study area presents loessic sediments with low percentages of fragments of volcanic glass with little weathering degree (Martínez and Osterrieth 2013). Several creeks of the Buenos Aires Province present a close relationship with groundwater, due to a water inflow induced by the effects of the pumping of water wells (Martín and García 2009). Based on this influence, the knowledge of the mobility of contaminants in surface water is relevant since the mobile-labile fraction could contribute with contaminants to groundwater, affecting its chemical quality (Kruse et al. 2004).

Evaluations of mobility of As in surface waters have not been carried out in this area; they were only performed in underground waters of industrial areas of the south of the province (Bahía Blanca city; Paoloni et al. 2009; Puccia et al. 2015) and rural areas of the central and northern Chaco-Pampean plain (Smedley et al. 2005).

The aim of this study was to evaluate adsorption, mobility and water availability of As in freshwater sediments, with agricultural, livestock and urban soil uses.

\section{Materials and methods}

\section{Study area and sampling sites}

El Durazno creek is located in the southeast of the Buenos Aires Province $\left(38^{\circ} 10^{\prime} \mathrm{S} 57^{\circ} 50^{\prime} \mathrm{W}\right.$, Argentina), in the Chaco-Pampean plain, with a slope between 0.3 and $0.7 \%$ (Kruse 1986). Due to the low slope of the area, the downward flow or vertical movement (leaching of contamination and percolation) is more prevalent than those of horizontal (runoff), being the infiltration process a key factor in the water balance (Quiroz Londoño et al. 2012). The texture of sediment creek corresponds to silt associated with fine sand and low percentages of clay; they are characterized by a fine particle size, $<0.1 \mathrm{~mm}$, being mainly $<0.05 \mathrm{~mm}$ (Cohen 2014).

The climate of the region is classified as semi-humid, with annual precipitation values ranging from 703 to $1400 \mathrm{~mm}$ per year, with an average of $943 \mathrm{~mm}$ (Romanelli et al. 2011). Climatic, geological and geomorphological features of Chaco-Pampean plain allow the development of highly productive agricultural soils, being one of the areas with the greatest agricultural development in Argentina. In the studied watershed, the Rural Zone presents important agricultural activities, which are highly dependent on the availability of both surface and underground water resources (Quiroz Londoño et al. 2012). The El Durazno creek watershed is characterized by agricultural and livestock activities, involving the use of phosphate fertilizers, which can be a potential anthropogenic source of arsenic to the environment (Tremearne and Jacob 1941; Benson et al. 2014). The watershed of El Durazno creek presents heterogeneous areas based on the activities conducted on their margins. There are urbanized areas (road, power lines, sewage, residential buildings of low and high density, with dispersed and continuous distribution), touristic-recreational areas (recreation parks, beach resorts) and agricultural and livestock areas. Sampling sites were established along the creek, from its origin, at the Rural Zone (with a significant agricultural livestock and use of pesticides and fertilizers), to its mouth at the Coast Zone (without farming and/or livestock), going through the city, Urban Zone. The sampling was conducted in March of 2014, with a record of rainfall of $219.47 \mathrm{~mm}$, corresponding to a period of low precipitations.

\section{Sampling of water and sediments}

Surface sediment samples ( $n=3$ by site) were collected by PVC cores (10 cm in length), and creek surface water ( $n=3$ by site) collection was performed with polypropylene bottles $(250 \mathrm{~mL})$. Bottles and cores were previously washed with $\mathrm{HNO}_{3} 1 \%$ and rinsed with distilled water. Sediments were dried at room temperature until constant weight and then homogenized in porcelain mortar, keeping in plastic bags until analyses. The core sample of Urban Zone presented different texture, being subsampling, indicated by Urban Zone (a) (the upper layer) and Urban Zone (b) (the deeper layer), and they were analyzed individually. Samples of water were acidified $(2 \mathrm{~mL} \mathrm{HCl} 30 \% \mathrm{w} / \mathrm{w}$, Merck) and immediately were taken, ascorbic acid (SigmaAldrich) was added to prevent oxidation; they were kept at $4{ }^{\circ} \mathrm{C}$ until analyses.

\section{Determination of total and labile As in sediments}

To determine total As, $1 \mathrm{~g}$ of dry sediment was digested with concentrated perchloric $\left(\mathrm{HClO}_{4}, \mathrm{Merck}\right)$ and nitric $\left(\mathrm{HNO}_{3}\right.$, Merck) acids (1:3) in glycerin bath to reduce the volume to $1 \mathrm{~mL}$ (FAO/SIDA 1983). After that, the samples were diluted to final volume with nitric acid (1\%). Total As was determined by atomic absorption spectroscopy (AAS) with graphite furnace mode, using the Shimadzu AA-6800 equipment. The standard curve was performed using a stock solution of As (1000 mg L ${ }^{-1}$, Titrisol, Merck). Blanks of reactive and Certified Reference Material (CRM marine sediments MESS-3, National Research Council of 
Canada) were treated under the same conditions of samples. Concentrations of As determined in the CRM were in accordance with those certified values $(p<0.05)$. The recovery of standard was $95 \%$, and the limit of detection was $5 \mu \mathrm{g} \mathrm{kg}^{-1}$. The analyses were performed by duplicate, and the results were expressed in $\mathrm{mg} \mathrm{kg}^{-1}$ in dry weight.

To determine the labile fraction of As, $1 \mathrm{~g}$ of sediment was treated with $50 \mathrm{~mL}$ of hydrochloric acid ( $\mathrm{HCl} \mathrm{1M}$ ), shaken during $24 \mathrm{~h}$ and then centrifuged at $5000 \mathrm{rpm}$ during $5 \mathrm{~min}$, extracting the supernatant (Luoma 1990). Arsenic was determined by AAS with flame mode. The recovery of standard was $90 \%$, and the limit of detection was $0.05 \mathrm{mg} \mathrm{kg}^{-1}$. The analyses were performed by duplicate, and the results were expressed as $\mathrm{mg} \mathrm{kg}^{-1}$ in dry weight.

\section{Determination of total As in water}

Ten milliliters of sample was treated with $2 \mathrm{~mL}$ of sodium sulfite $\left(\mathrm{Na}_{2} \mathrm{SO}_{3}, 2 \mathrm{M}\right.$ Sigma-Aldrich) and $5 \mathrm{~mL}$ of hydrochloric acid ( $\mathrm{HCl} 30 \% \mathrm{w} / \mathrm{w}$, Merck) and heated to $90^{\circ}$ during $30 \mathrm{~min}$; this procedure reduces all $\mathrm{As}$ to $\mathrm{As}^{3+}$. After that, the samples were cooled to room temperature (20-25 ${ }^{\circ} \mathrm{C}$ ) and measurements were performed by anodic stripping voltammetry (Bodewig et al. 1982). The limit of detection was $0.5 \mu \mathrm{g} \mathrm{L}^{-1}$, and the results were expressed in $\mu \mathrm{g} \mathrm{L}^{-1}$. A standard curve was performed with a stock solution of As (1000 $\mathrm{mg} \mathrm{L}^{-1}$, Merck Titrisol), and blank of reactive was treated under the same conditions of samples. In order to validate the results, standard recovery was carried out obtaining values of $102.3 \pm 3.1 \%$. Arsenic(III) was measured in water samples without the treatment of the reduction process (Bodewig et al. 1982).

\section{Determination of chemical parameters in sediments and water}

The $\mathrm{pH}$ of water was determined by potentiometry using a multiparameter analyzer (Horiba U-10), and dissolved oxygen was determined by the method of Winkler (Strickland and Parsons 1972).

In sediments, iron ( $\mathrm{Fe})$ and manganese $(\mathrm{Mn})$ concentrations were determined by AAS in the acidic extraction obtained in the determination of total As, using flame and graphite furnace modes, respectively. The limits of detection were $0.05 \mathrm{mg} \mathrm{kg}^{-1}$ for $\mathrm{Fe}$ and $5 \mu \mathrm{g} \mathrm{kg}^{-1}$ for $\mathrm{Mn}$. The concentrations of soluble phosphates (SP) were determined by the acid yellow vanadomolybdophosphoric method by UV-visible spectroscopy (Carrasquero and Adams 2011). Concentrations of $\mathrm{Fe}, \mathrm{Mn}$ and $\mathrm{SP}$ were expressed in $\mathrm{mg} \mathrm{kg}^{-1}$. The $\mathrm{pH}$ determination in sediments was performed applying the potentiometric method with water mixture (1 g:10 mL) (Fields and Parrot 1972). The technique of Walkley-Black was applied to determine the oxidizable organic matter (OM), using potassium dichromate as oxidant (Walkley and Black 1934), and the results were expressed in percentage. The cation-exchange capacity (CEC) was determined by the ammonium acetate method (IRAM-SAGyP 29577-1 2012), and the results were expressed in meq $100 \mathrm{~g}^{-1}$.

\section{Statistical analyses}

Median and standard error were calculated for As levels in water and sediments and chemical parameters. Homoscedasticity of data was checked by the Levene test $(p<0.05)$ (Zar 2010). The differences of As and chemical parameters among matrices, fractions and sampling sites were performed by Kruskal-Wallis test. All analyses were conducted with Statistica 6.0 (Statsoft, Inc.).

\section{Results and discussion}

The textural characteristic of the analyzed sediments corresponded to fine grain size (clay and silt). The texture of the cores was vertically homogeneous except in the Urban Zone, where two different colors/textures were observed; the top half [5 cm, Urban Zone (a)] was silty loam sediment (dark black-brown coloration, $4.8 \pm 0.4 \%$ of organic matter), while the lower half [5 $\mathrm{cm}$, Urban Zone (b)] corresponded to silty clay sediment (clear brown-beige color, $1.1 \pm 0.1 \%$ of organic matter). Sediment maximum concentrations of total As $\left(15.9 \pm 0.6 \mathrm{mg} \mathrm{kg}^{-1}\right)$ were found in Urban Zone (b), that is, the finest grain size fraction, being significantly higher $(p<0.05)$ to the values found in the other sampling sites, even in the upper section of the same zone (Table 1). The concentrations of As were similar or lower than data reported for surface sediments (loess with similar texture) of the Chaco-Pampean plain: 3-18 $\mathrm{mg} \mathrm{kg}^{-1}$ (Smedley et al. 2005), 6-25 mg kg${ }^{-1}$ (Nicolli et al. 2012) and 0.25-28 $\mathrm{mg} \mathrm{kg}^{-1}$ (Rosso et al. 2013). Sediments are source and sink of As; in addition, they are the most important route of exposure for those aquatic organisms closely associated with them. Therefore, to assess the mobility of this metalloid to water column and pore water is relevant to the aquatic environment. Related to labile concentrations of As, the maximum levels were also found in Urban Zone (b) $\left(6.5 \pm 0.5 \mathrm{mg} \mathrm{kg}^{-1}\right)$ (Table 1), with $41 \%$ of lability. This median value was significantly higher $(p<0.05)$ than those found in Rural and Coast Zones, and very similar to the fraction (a). Besides, the highest percentage of lability was found in Urban Zone (a) (96\%). The significantly higher $(p<0.05)$ concentrations of $\mathrm{Fe}$ in fraction (b) than those found in fraction (a), and the percentage of lability in both fractions 
Table 1 Arsenic concentrations found in sediments (median \pm standard error, dry weight) and in water (median \pm standard error) of the sampling sites along of the creek El Durazno

\begin{tabular}{lclcc}
\hline Sampling sites & Total As (S) $\left(\mathrm{mg} \mathrm{kg}^{-1}\right)$ & Labile As $(\mathrm{S})\left(\mathrm{mg} \mathrm{kg}^{-1}\right)$ (lability percentage) & Total As(W) $\left(\mu \mathrm{g} \mathrm{L}^{-1}\right)$ & $\mathrm{Arsenic}^{(\mathrm{III})}(\mathrm{W})\left(\mu \mathrm{g} \mathrm{L} \mathrm{L}^{-1}\right)$ \\
\hline Coast Zone & $7.4 \pm 0.9$ & $4.8 \pm 1.1(66 \%)$ & $17.4 \pm 0.2$ & $2.4 \pm 0.2$ \\
Urban Zone (a) & $6.8 \pm 0.3$ & $6.1 \pm 0.6(96 \%)$ & $6.6 \pm 0.6$ & $1.0 \pm 0.0$ \\
Urban Zone (b) & $15.9 \pm 0.6$ & $6.5 \pm 0.5(41 \%)$ & $34.6 \pm 0.4$ & $1.0 \pm 0.0$ \\
Rural Zone & $5.4 \pm 0.3$ & $2.8 \pm 0.2(52 \%)$ & $2.3 \pm 0.1$ \\
\hline
\end{tabular}

Urban Zone (a), upper layer of core sample; Urban Zone (b), deeper layer of core sample; (S), sediment; (W), water

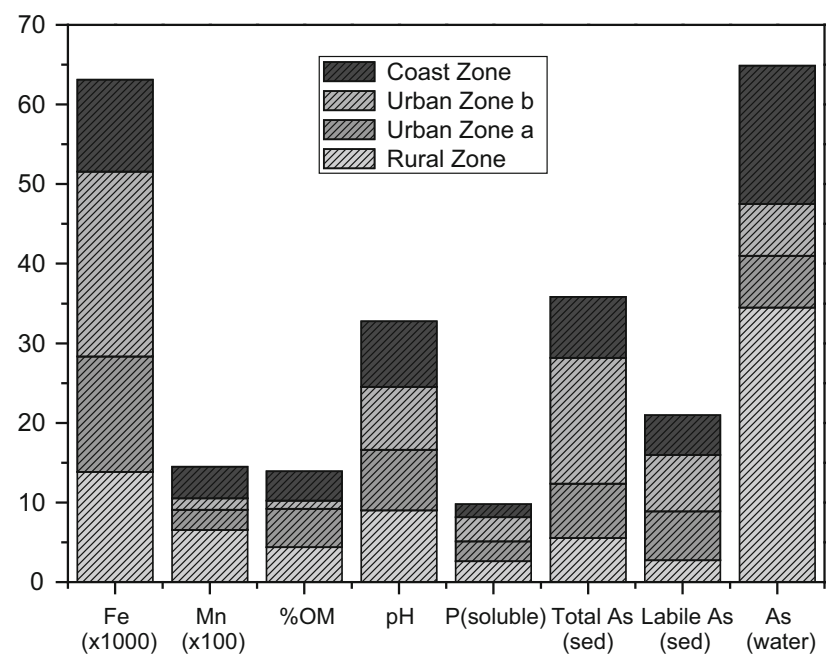

Fig. 1 Distribution of total and labile arsenic $\left(\mathrm{mg} \mathrm{kg}^{-1}\right)$, organic matter $(\%), \mathrm{pH}$, soluble phosphorus $\left(\mathrm{mg} \mathrm{kg}^{-1}\right)$, iron $\left(\mathrm{mg} \mathrm{kg}^{-1}\right)$ and manganese $\left(\mathrm{mg} \mathrm{kg}^{-1}\right)$ in sediments, and total arsenic in water $\left(\mu \mathrm{g} \mathrm{L}^{-1}\right)$ in the sampling sites studied

(Fig. 1), would suggest that levels of As in water found in this sampling site would be released from sediments of the upper section; however, those maximum levels of total As in sediments were found in the deeper fraction (Table 1). The result found in this zone could be associated with the higher levels of $\mathrm{Fe}$, suggesting the close relationship between $\mathrm{As}$ and $\mathrm{Fe}$. The importance of Fe(III) oxyhydroxides in sediments was established as primary sorbents for inorganic As in oxidized conditions (Smedley and Kinniburgh 2002; Stollenwerk 2003; Root et al. 2007). Some studies have also associated the presence of As with Mn oxide (Smedley et al. 2005; Chapagain et al. 2009; Borgnino et al. 2012). Moreover, analyses of chemical fractionation found that As is present in the residual fraction with highest percentages, coinciding with the high amount of Fe and Mn (Sarkar et al. 2014). Based on Mn levels found in both fractions (Table 2), being significantly higher $(p<0.05)$ in Urban Zone (a), it would be possible to suggest that $\mathrm{Mn}$ oxides may be involved on the adsorption of As in sediments, even though in a lower degree than $\mathrm{Fe}$. This greater participation of Fe oxides in the adsorption of As with respect to those of Mn was also informed by Smedley et al. (2005) in sediments of the Chaco-Pampean areas. In addition, it has been demonstrated that the adsorption of As on iron oxides plays a dominant role in oxidizing environments (De Mello et al. 2006; Cordos et al. 2006; US/EPA 2007; Müller et al. 2007; Root et al. 2007); being remarkable that the sediments in the study area are strongly oxidized (Smedley and Kinniburgh 2002). Even, the relationship between concentrations of $\mathrm{Fe}$ and $\mathrm{Mn}$ showed the opposite trend, where the maximum levels of $\mathrm{Fe}$ coincide with the minimum of Mn, mainly in Urban Zone (b) (Table 2). Likewise, these maximum concentrations coincided with the highest levels of total and labile As in sediments. The significantly lower As levels in water $(p<0.05)$ would seem to indicate very low available concentrations in relation to those found in the labile fraction of the sediments (Table 1), where Rural Zone presented the highest availability, meaning dissolved As in the water column. However, besides the percentages of lability and As concentrations in sediments (both in $\mathrm{mg} \mathrm{kg}^{-1}$ ), levels in water (expressed in $\mu \mathrm{g} \mathrm{L}^{-1}$ ) would be indicating that its mobility to the water column has been considerably low in all sampling sites.

The OM percentages presented similar values among sampling sites with the exception of Urban Zone (b), which was significantly lower $(p<0.05)$ (Table 2$)$; additionally, this parameter presented an inverse relationship with $\mathrm{Fe}$ content, coinciding the lowest percentage with the highest concentration of this element. Furthermore, the lowest OM value coincided with the highest concentrations of total and labile As in sediments (Table 1). Moreover, some studies have reported that large amounts of $\mathrm{OM}$ and a low $\mathrm{Fe}$ oxide content should favor As leaching from soils and sediments (De Mello et al. 2006). The result obtained would indicate that $\mathrm{OM}$ would not be responsible, or in minor relevance, of the adsorption processes of As, due to the sediments presented higher levels of Fe. Chen et al. (2002) reported that $\mathrm{OM}$ tends to be poorly correlated with total As in surface sediments, when they were compared with $\mathrm{Fe}, \mathrm{Al}$, and $\mathrm{P}$, suggesting that its contribution to the As retention in soils and sediments is limited. By other way, Zan et al. (2014) assessing adsorption processes of As in sediments of Chinese lakes, informed that binding capacity of $\mathrm{Fe}$ and 
Table 2 Chemical environmental parameters found in sediments (median \pm standard error, dry weight) of the sampling sites along of the creek El Durazno

\begin{tabular}{llllllr}
\hline Sampling sites & $\mathrm{Fe}\left(\mathrm{mg} \mathrm{kg}^{-1}\right)$ & $\mathrm{Mn}\left(\mathrm{mg} \mathrm{kg}^{-1}\right)$ & $\mathrm{OM}(\%)$ & $\mathrm{SP}\left(\mathrm{mg} \mathrm{kg}^{-1}\right)$ & $\mathrm{CEC}\left({\left.\mathrm{meq} 100 \mathrm{~g}^{-1}\right)}^{\mathrm{pH}}\right.$ \\
\hline Coast Zone & $11,563 \pm 461$ & $336.5 \pm 53.8$ & $2.9 \pm 1.1$ & $154.0 \pm 9.9$ & 38.0 & $8.2 \pm 0.2$ \\
Urban Zone (a) & $14,758 \pm 535$ & $252.4 \pm 5.1$ & $4.8 \pm 0.4$ & $262.0 \pm 17.2$ & 36.6 & $7.6 \pm 0.1$ \\
Urban Zone (b) & $23,500 \pm 306$ & $140.6 \pm 5.1$ & $1.1 \pm 0.1$ & $299.5 \pm 26.4$ & 37.0 & $7.9 \pm 0.0$ \\
Rural Zone & $13,690 \pm 355$ & $662.1 \pm 44.6$ & $4.4 \pm 0.1$ & $260.5 \pm 16.0$ & 25.3 & $9.2 \pm 0.1$ \\
\hline
\end{tabular}

Urban Zone (a), upper layer of core sample; Urban Zone (b), deeper layer of core sample; OM, oxidizable organic matter; SP, soluble phosphorus; CEC, cation-exchange capacity

Mn (hydro)oxides was stronger than carbonates, organic matter and sulfides.

In the Urban Zone (b), the maximum concentrations of SP in sediments (Table 2) were observed and coincided with the highest total As levels (Table 1); however, a direct relationship between them was not found. Phosphate, with similar chemical characteristics to As, tends also to precipitate with Fe (Smedley and Kinniburgh 2002). The dominant surface complex of arsenate is consistent with infrared studies of phosphate on iron (hydr)oxides (Parfitt et al. 1975; Arai and Sparks 2001), a factor supporting the analogous strong retention of phosphate.

Related to $\mathrm{pH}$, both matrices analyzed showed alkaline values (water: 7.2-7.7; sediments: 7.6-9.0) (Table 2), without significant differences between sampling sites $(p>0.05)$; the same situation was found for dissolved oxygen (8.1-9.9 mg L ${ }^{-1}$ ). Consequently, a relationship of $\mathrm{pH}$ (sediments and water) and dissolved oxygen with labile and total As concentrations, in both matrices, was not found. The maximum $\mathrm{pH}$ in sediment ( 9.0 in Rural Zone) coincided with its lower levels of total As, and the highest concentrations in water. Casiot et al. (2007) reported that in alkaline water As is adsorbed on Fe oxyhydroxides and consequently limits its solubility. Likewise $\mathrm{pH}$, the minimum values of CEC (Table 2) were also found in this zone, and a correlation with lability was not found. Contrary to the result found in this study, a positive correlation between CEC and As adsorption was reported ( $\mathrm{Li}$ et al. 2011). Meanwhile, Chapagain et al. (2009) suggested that CEC does not have a direct influence on electrostatic retention, although a positive correlation As vs CEC was found, but they associated with clay content. Likewise, the exchange capacities obtained were in agreement with published ranges for the area: $8-23 \mathrm{cmol} \mathrm{kg}^{-1}$ (=meq $100 \mathrm{~g}^{-1}$ ) (Morrás 1995) and 30-40 meq $100 \mathrm{~g}^{-1}$ (Martínez and Osterrieth 2013).

Meanwhile, the levels of total As in surface waters were significantly lower $(p<0.05)$ than those found in sediments (Table 1), being the highest total As concentration in Rural Zone $\left(34.6 \pm 0.4 \mu \mathrm{g} \mathrm{L}^{-1}\right)$ and the lowest in those from Urban Zone $\left(6.6 \pm 0.6 \mu \mathrm{g} \mathrm{L}^{-1}\right)$. The water As concentrations of both sampling sites were lower than information reported for other freshwater watersheds from the
Buenos Aires Province $\left(140-171 \mu \mathrm{g} \mathrm{L}^{-1}\right.$, Rosso et al. 2013; 58-413 $\mu \mathrm{g} \mathrm{L}^{-1}$, Volpedo et al. (2012) and Puntoriero et al. (2014). Furthermore, the concentrations found in this study and those published for Buenos Aires Province were lower than levels in groundwater with naturally high concentrations and harmful consequences to human health (groundwater of northern La Pampa Province $>7490 \mu \mathrm{g} \mathrm{L}^{-1}$, Smedley et al. 2005; shallow aquifer from Santiago del Estero Province $<4.8 \mathrm{mg} \mathrm{L}^{-1}$; Bundschuh et al. 2004).

To complement the results of total As obtained in water, concentrations of $\mathrm{As}(\mathrm{III})$ were also determined, being between $1.0 \pm 0.0$ and $2.4 \pm 0.2 \mu \mathrm{g} \mathrm{L}^{-1}$. These values are represented as a lower percentage of the total concentrations (6-15\%) found; related to the higher toxicity of As(III) with respect to As (V), it is important to highlight it.

\section{Conclusion}

The As concentrations in water were lower than those found in sediments, with different order of magnitude, even the As(III) levels were negligible. The preliminary findings suggest that the co-precipitation and adsorption on iron oxides would be the major route of immobilization of As in sediments; meanwhile, Mn did not present an outstanding contribution to the retention. CEC, $\mathrm{pH}$ and OM of sediments did not show an influence on the mobility of As. Finally, the different uses of the surrounding soils to the creek did not evidence and influence on the adsorption and mobility of As; the natural mineral composition, mainly those associated with $\mathrm{Fe}$ and Mn, would define both processes.

Acknowledgements This work was partially supported by grants from National Scientific and Technical Research Council, CONICET (PIP0348/2010) and Mar del Plata University (EXA640/13).

\section{References}

Arai Y, Sparks DL (2001) ATR-FTIR spectroscopic investigation of phosphate adsorption mechanisms at the ferrihydrite-water interface. J Colloid Interfaces Sci 241:317-326 
Benson NQ, Anake WU, Etesin UM (2014) Trace metals levels in inorganic fertilizers commercially available in Nigeria. JSRR 3:610-620

Bodewig FG, Valenta P, Nürnberg HW (1982) Trace determination of As (III) and As (V) in natural waters by differential pulse anodic stripping voltammetry. Fresen Z Anal Chem 311:187-191

Borgnino L, De Pauli CP, Depetris PJ (2012) Arsenate adsorption at the sediment-water interface: sorption experiments and modelling. Environ Earth Sci 65(2):441-451

Bundschuh J, Farias B, Martin R, Storniolo A, Bhattacharya P, Cortes J, Bonorino G, Albouy R (2004) Groundwater arsenic in the ChacoPampean Plain, Argentina: case study from Robles county, Santiago del Estero Province. Appl Geochem 19:231-243

CAA (Código Alimentario Argentino) (2007) Capítulo XII. Bebidas hídricas, agua y agua gasificada. In: http://www.anmat.gov.ar/ alimentos/codigoa/Capitulo_XII.pdf. Accessed: 29 de septiembre de 2016

Carrasquero A, Adams M (2011) Estudio del complejo amarillo vanadomolibdofosfórico para el análisis de fósforo en suelos. Venesuelos 3:83-88

Casiot C, Ujevic M, Munoz M, Seidel JL, Elbaz-Poulichet F (2007) Antimony and arsenic mobility in a creek draining an antimony mine abandoned 85 years ago (upper Orb basin, France). Appl Geochem 22(4):788-798

Chapagain SK, Shrestha S, Du Laing G, Verloo M, Kazama F (2009) Spatial distribution of arsenic in the intertidal sediments of River Scheldt, Belgium. Environ Int 35(3):461-465

Chen M, Ma LQ, Harris WG (2002) Arsenic concentrations in Florida surface soils: influence of soil type and properties. Soil Sci Soc Am J 66:632-640

Cohen C (2014) Línea de base Ambiental de la Cuenca de los Arroyos El Durazno y La Totora. Partido de General Alvarado, Provincia de Buenos Aires. Tesis de Licenciatura en Geografía. Universidad Nacional de Mar del Plata, pp 102

Cordos EA, Frentiua T, Pontaa M, Marginean L, Abrahamb B, Roman C (2006) Distribution study of inorganic arsenic (III) and (V) species in soil and their mobility in the area of Baia-Mare, Romania. Chem Spec Bioavailab 18(1):11-25

De Mello JWV, Roy WR, Talbott JL, Stucki JW (2006) Mineralogy and arsenic mobility in arsenic-rich brazilian soils and sediments. J Soils Sedim 6(1):9-19

FAO/SIDA (1983) Manual of methods in aquatic environmental research, part 9. Analyses of metals and organochlorines in fish. FAO Fisheries/Technical Paper, pp 212

Fendorf S, Herbel MJ, Tufano KJ, Kocar BD (2008) Biogeochemical processes controlling the cycling of arsenic in soils and sediments. In: Huang PM, Violante A, Huang PM, Gadd GM (eds) Biophysico-chemical processes of heavy metals and metalloids in soil environments. Wiley, pp 313-338

Fields and Parrot (1972) Reaction pH. In: Soil Conservation Service (ed) Soil survey laboratory methods and procedures for collecting soil samples. US, Department of Agriculture, Washington, DC, $\mathrm{p} 86$

Heck JE, Andrew AS, Onega T, Rigas JR, Jackson BP, Karagas MR, Duell EJ (2009) Lung cancer in a US population with low to moderate arsenic exposure. Environ Health Perspect 117:1718-1723

IRAM-SAGyP 29577-1 (2012) Calidad ambiental. Calidad de suelo. Capacidad de intercambio catiónico y cationes básicos intercambiables. Parte: Determinación en suelos ligeramente ácidos a neutros y no calcáreo. In: http://aplicaciones.iram.org.ar/. Accessed: 29 de septiembre de 2015

Kruse E (1986) Aspectos geohidrológicos de la región sudoriental de Tandilla. Cuencas de los Aos. Vivoratá, las Brusquitas y el Durazno. Asociación Geológica Argentina, Revista 41:367-374
Kruse E, Varela L, Laurencena P, Deluchi M, Rojo A, Carol E (2004) Modificaciones del Ciclo Hidrológico en un Área del Noreste de la Provincia de Buenos Aires. Argentina. Serie Hidrogeología y aguas subterráneas 11:131-139. Instituto Geológico Minero de España. ISBN 84-7840-539-9. Madrid

Li Z, Hong H, Jean JS, Koski AJ, Liu CC, Reza S, Randolph JJ, Kurdas SR, Friend JH, Antinucci SJ (2011) Characterization on arsenic sorption and mobility of the sediments of Chia-Nan Plain, where Blackfoot disease occurred. Environ Earth Sci 64(3):823-831

Luoma SN (1990) Processes affecting metal concentrations in estuarine and coastal marine sediments. In: Furness RW, Rainbow PS (eds) Heavy metals in the marine environment. CRC Press Inc, Boca Raton, pp 51-66

Ma J, Guo H, Lei M, Zhou X, Li F, Yu T, Wei R, Zhang H, Zhang X, $\mathrm{Wu} \mathrm{Y}$ (2015) Arsenic adsorption and its fractions on aquifer sediment: effect of $\mathrm{pH}$, arsenic species, and iron/manganese minerals. Water Air Soil Pollut 226(8):1-15

Mandal BK, Suzuki KT (2002) Arsenic round the world: a review. Talanta 58:201-235

Martín AV, García MC (2009) Contaminación química de aguas para consumo en la periferia urbana de la localidad de Miramar, Provincia de Buenos Aires, Argentina. Nadir: Revista electrónica de geografía austral. Año 1:12-30

Martínez D, Osterrieth M (2013) Hydrogeochemistry and pollution effects of an aquifer in Quaternary loess like sediments in the landfilling area of Mar del Plata, Argentina. Revista Facultad Ingeniería, Universidad de Antioquia 66:9-23

Mohan D, Pittman CU Jr (2007) Arsenic removal from water/ wastewater using adsorbents-a critical review. J Hazard Mater 142:1-53

Morrás HJ (1995) Mineralogy and cation exchange capacity of the fine silt fraction in two soils from the southern Chaco Region (Argentina). Geoderma 64:281-295

Müller K, Daus B, Morgenstern P, Wennrich R (2007) Mobilization of antimony and arsenic in soil and sediment samplesevaluation of different leaching procedures. Water Air Soil Pollut 183(1-4):427-436

Nicolli HB, Bundschuh J, Blanco MC, Tujchneider OF, Panarello HO, Dapeña C, Rusansky JE (2012) Arsenic and associated trace-elements in groundwater from the Chaco-Pampean plain, Argentina: results from 100 years of research. Sci Total Environ 429:36-56

Paoloni JD, Sequeira ME, Espósito ME, Fiorentino CE, Blanco MDC (2009) Arsenic in water resources of the Southern Pampa Plains, Argentina. J Environ Public Health 2009:1-7

Parfitt RL, Atkinson RJ, Smart RSC (1975) Mechanism of phosphate fixation by iron oxides. Soil Sci Soc Am J 39:837-841

Pérez Carrera A, Fernández Cirelli A (2005) Arsenic concentration in water and bovine milk in Cordoba, Argentina. Preliminary results. J Dairy Res 72:122-124

Puccia V, Limbozzi F, Avena M (2015) Arsenic in porewaters of the unsaturated zone of an Argentinean watershed: adsorption and competition with carbonate as important processes that regulate its concentration. Aquat Geochem 21:513-534

Puntoriero M, Volpedo AV, Fernández Cirelli A (2014) Arsenic, Fluoride, and Vanadium in surfacewater (Chasicó Lake, Argentina). Front Environ Sci 2:1-5

Puntoriero ML, Fernandez Cirelli A, Volpedo AV (2015) Geochemical mechanisms controlling the chemical composition of groundwater and surface water in the southwest of the Pampean plain (Argentina). J Geochem Explor 150:64-72

Quiroz Londoño OM, Martinez DE, Massone HE (2012) Evaluación Comparativa de Métodos de Cálculo de Recarga en Ambientes de Llanura. La Llanura Interserrana Bonaerense (Argentina), 
como caso de estudio. Comparative Assessment of Recharge Estimation. Dyna 79:15-25

Romanelli A, Quiroz Londoño OM, Massone HE, Martínez DE, Bocanegra E (2011) El agua subterránea en el funcionamiento hidrológico de los humedales del Sudeste Bonaerense, Provincia de Buenos Aires, Argentina. Boletín Geológico y Minero 121:373-386

Root RA, Dixit S, Campbell KM, Jew AD, Hering JG, O'Day PA (2007) Arsenic sequestration by sorption processes in high-iron sediments. Geochimica Cosmo Acta 71(23):5782-5803

Rosso JJ, Puntoriero ML, Troncoso JJ, Volpedo AV, Fernández Cirelli A (2011) Occurrence of fluoride in arsenic-rich surface waters: a case study in the Pampa Plain, Argentina. Bull Environ Contam Toxicol 87:409-413

Rosso JJ, Schenone NF, Carrera AP, Cirelli AF (2013) Concentration of arsenic in water, sediments and fish species from naturally contaminated rivers. Environ Geochem Health 35:201-214

Sarkar SK, Favas PJC, Rakshit D, Satpathy KK (2014) Geochemical speciation and risk assessment of heavy metals in soils and sediments. In: Environmental risk assessment of soil contamination, chap 25. InTech, pp 723-757

Smedley PL, Kinniburgh DG (2002) A review of the source, behaviour and distribution of arsenic in natural waters. Appl Geochem 17:517-568

Smedley PL, Kinniburgh DG, Macdonald DMJ, Nicolli HB, Barros AJ, Tullio JO, Pearce JM, Alonso MS (2005) Arsenic associations in sediments from the loess aquifer of La Pampa, Argentina. Appl Geochem 20:989-1016
Stollenwerk KG (2003) Geochemical processes controlling transport of arsenic in groundwater: a review of adsorption. In: Welch $\mathrm{AH}$, Stollenwerk KG (eds) Arsenic in Ground Water: Geochemistry and Occurrence. Kluwer Academic Publishers, Boston, pp 67-100

Strickland JDH, Parsons TR (1972) A practical handbook of seawater analysis, 3rd edn. Bulletin of Fisheries Research Board of Canada, Ottawa, p 167

Tremearne TH, Jacob KD (1941) Arsenic in natural phosphates and phosphate fertilizers. Tech Bull 781:1-41

US/EPA (2007) Monitored natural attenuation of inorganic contaminants in groundwater. Assessment for non-radionuclides including arsenic, cadmium, chromium, copper, lead, nickel, nitrate, perchlorate, and selenium, vol 2. EPA/600/R-07/140, p 124

Volpedo A, Puntoriero ML, Fernández Cirelli A (2012). Riesgo potencial de las altas concentraciones de arsénico en el Lago Chasicó (Buenos Aires, Argentina). In: VII Congreso de Medio Ambiente (La Plata, 2012)

Walkley A, Black IA (1934) An examination of Degtjareff method for determining soil organic matter and a proposed modification of the chromic acid titration method. Soil Sci 37:29-37

World Health Organization (WHO) (2006) http://www.who.int. Accessed: 29 de septiembre de 2015

Zan F, Huo S, Zhang J, Zhang L, Xi B, Zhang L (2014) Arsenic fractionation and contamination assessment in sediments of thirteen lakes from the East Plain and Yungui Plateau Ecoregions, China. J Environ Sci 26:1977-1984

Zar JH (2010) Biostatistical analysis, 5th edn. Prentice Hall Inc, Englewood Cliffs, p 944 